\title{
Dust-Firing of Straw and Additives \\ Ash Chemistry and Deposition Behavior
}

Wu, Hao; Glarborg, Peter; Frandsen, Flemming; Dam-Johansen, Kim; Jensen, Peter Arendt

\section{Published in:}

Energy \& Fuels

Link to article, DOI:

10.1021/ef200452d

Publication date:

2011

Document Version

Publisher's PDF, also known as Version of record

Link back to DTU Orbit

Citation (APA):

Wu, H., Glarborg, P., Frandsen, F., Dam-Johansen, K., \& Jensen, P. A. (2011). Dust-Firing of Straw and Additives: Ash Chemistry and Deposition Behavior. Energy \& Fuels, 25(7), 2862-2873.

https://doi.org/10.1021/ef200452d

\section{General rights}

Copyright and moral rights for the publications made accessible in the public portal are retained by the authors and/or other copyright owners and it is a condition of accessing publications that users recognise and abide by the legal requirements associated with these rights.

- Users may download and print one copy of any publication from the public portal for the purpose of private study or research.

- You may not further distribute the material or use it for any profit-making activity or commercial gain

- You may freely distribute the URL identifying the publication in the public portal

If you believe that this document breaches copyright please contact us providing details, and we will remove access to the work immediately and investigate your claim. 


\title{
Dust-Firing of Straw and Additives: Ash Chemistry and Deposition Behavior
}

\author{
Hao Wu, ${ }^{*}$ Peter Glarborg, Flemming Jappe Frandsen, Kim Dam-Johansen, and Peter Arendt Jensen
}

Department of Chemical and Biochemical Engineering, Technical University of Denmark, Søltofts Plads, Building 229, DK-2800 Kongens Lyngby, Denmark

Supporting Information

\begin{abstract}
In the present work, the ash chemistry and deposition behavior during straw dust-firing were studied by performing experiments in an entrained flow reactor. The effect of using spent bleaching earth (SBE) as an additive in straw combustion was also investigated by comparing with kaolinite. During dust-firing of straw, the large $(>\sim 2.5 \mu \mathrm{m})$ fly ash particles generated were primarily molten or partially molten spherical particles rich in $\mathrm{K}, \mathrm{Si}$, and $\mathrm{Ca}$, supplemented by Si-rich flake-shaped particles. The smaller fly ash particles $(<\sim 2.5 \mu \mathrm{m})$ were predominantly formed from the nucleation, condensation, and coagulation of the vaporized $\mathrm{K}$, $\mathrm{Cl}$, $\mathrm{S}$, and $\mathrm{P}$ species. Approximately $70 \%$ of $\mathrm{K}$ in the fly ash from straw combustion was water-soluble, and $\mathrm{KCl}$ was estimated to contribute to more than $40 \%$ of the water-soluble $\mathrm{K}$. With the addition of SBE to straw dust-firing, the $\mathrm{Cl}$ retention in ash was reduced, the $\mathrm{SO}_{2}$ emission was increased, and the formation of water-soluble alkali species was decreased. Compared to kaolinite, the inhibiting effect of SBE on alkali chloride formation was slightly less pronounced at a similar $\mathrm{K} /(\mathrm{Al}+\mathrm{Si})$ molar ratio of the fuel mixture. The addition of SBE to straw dust-firing significantly decreased the $\mathrm{Cl}$ content of the deposits collected on a probe, both due to a dilution effect and chemical reactions. Compared to pure straw combustion, the deposition rate was slightly increased during the SBE addition, in spite of the considerably decreased deposition propensity. The results from the present work suggest that SBE could be a promising additive to be used in straw dust-firing.
\end{abstract}

\section{INTRODUCTION}

In order to achieve the European targets regarding reduction of greenhouse gases and increasing the use of renewable energy in $2020,{ }^{1}$ an important measure is to use biomass as fuel in highefficiency centralized electrical power plants. In Denmark, the utilization of biomass in power production has been primarily based on dedicated grate-fired power plants and cofiring in coalfired power plants. ${ }^{2-6}$ With an aim of increasing the biomass share in power production, an attractive solution is to convert the existing coal-fired power plants to $100 \%$ biomass dust-firing plants. Compared to traditional grate-fired plants, biomass dust-firing plants have higher load flexibilities, which can compensate the power production uncertainties induced by increasing wind power production in Denmark. ${ }^{7}$

Since biomass is fundamentally different from coal in terms of fuel properties and combustion behaviors, ${ }^{8}$ dust-firing of biomass may raise several technical challenges, such as flame stability and burnout, ash deposition and corrosion, deactivation of SCR catalyst, and ash utilization. Most of these issues are linked to the inorganic constituents in biomass. Compared to coal, biomass is often characterized by the large content of critical inorganic elements that may be easily vaporized during combustion. $^{9-12}$ The released critical inorganic elements, such as alkalis and chlorine, may form alkali chlorides and may lead to severe ash deposition and corrosion of superheaters in the boiler, ${ }^{3,13-19}$ thereby restricting the electrical efficiency of biomass-fired plants. ${ }^{2}$ Compared to grate-firing, ash deposition in biomass dust-firing may be more severe, due to the higher concentration of fly ash in the flue gas. Besides, the vaporized inorganic elements from biomass combustion may result in high concentrations of submicrometer particles in the flue gas. ${ }^{5,20-22}$ These particles may deteriorate the performance of SCR catalysts, through physical deposition and blocking of channels as well as chemical poisoning and deactivation. ${ }^{23-26}$

One possible approach to minimize the ash related problems during biomass combustion is to use additives that can convert the vaporized inorganic species to less harmful forms. ${ }^{20,27-34}$ The usable additives can be approximately categorized as $\mathrm{Al}-$ Si-based, S-based, P-based, and Ca-based, according to the major elements present in the additives. A typical example of the $\mathrm{Al}-$ Si-based additives is kaolinite, which has been proven to be very effective in minimizing the gaseous alkali concentration in the flue gas through the formation of alkali-aluminosilicates with high melting temperature and $\mathrm{HCl}^{35-39}$ Other $\mathrm{Al}-\mathrm{Si}$-based additives such as Bauxite, ${ }^{38}$ Emathlite, ${ }^{38}$ Bentonite, ${ }^{20}$ clay, ${ }^{20}$ quartz, ${ }^{40}$ and coal $\mathrm{ash}^{37}$ also showed some extent of decreasing effect on gaseous alkali concentrations. For S-based additives, the main effect is to convert the gaseous alkali chlorides in the flue gas to alkali sulfates, which are less harmful with respect to ash deposition and corrosion. ${ }^{39,41} \mathrm{~A}$ typical S-based additive is ammonium sulfate, which can not only convert the gaseous alkali chlorides to sulfates but also reduce the $\mathrm{NO}_{x}$ concentration in the flue gas. ${ }^{30,31}$ Other examples of S-based additives are aluminum sulfate, ${ }^{29}$ ferric sulfate, ${ }^{29}$ and elemental or gaseous sulfur. ${ }^{4,31} \mathrm{P}$-based additives usually refer to Ca-phosphates which are capable of capturing gaseous alkali through the formation of alkali-Ca-phosphates. ${ }^{20,40}$ Besides, a recent study showed
Received: March 24, 2011
Revised: $\quad$ May 28, 2011
Published: May 31, 2011 
Table 1. Properties of the Fuel and Additives

\begin{tabular}{llll}
\multicolumn{1}{c}{ properties } & straw & SBE & kaolinite \\
LHV (MJ/kg wet) & 16.28 & 16.13 & \\
moisture (wt \% wet) & 7.22 & 3.48 & 0.98 \\
ash (wt \% wet) & 3.87 & 44.44 & 85.20 \\
C (wt \% dry) & 47.50 & 38.90 & \\
H (wt \% dry) & 6.00 & 5.40 & 1.55 \\
$\mathrm{O}^{a}$ (wt \% dry) & 43.49 & 33.29 & 53.49 \\
$\mathrm{~N}$ (wt \% dry) & 0.43 & & \\
S (wt \% dry) & 0.08 & 0.18 & \\
Cl (wt \% dry) & 0.16 & 0.01 & \\
Si (wt\% dry) & 1.20 & 16.50 & 22.75 \\
Al (wt \% dry) & 0.01 & 3.00 & 20.05 \\
P (wt \% dry) & 0.06 & 0.02 & 0.03 \\
Fe (wt \% dry) & 0.01 & 0.86 & 0.58 \\
Ca (wt \% dry) & 0.29 & 0.24 & 0.03 \\
Mg (wt \% dry) & 0.06 & 0.56 & 0.17 \\
Na (wt \% dry) & 0.01 & 0.27 & 0.03 \\
K (wt \% dry) & 0.70 & 0.77 & 1.32 \\
a The oxygen content is calculated by the difference of the elemental \\
content.
\end{tabular}

that the addition of ammonium phosphate could also decrease the concentration of alkali chloride in flue gas, presumably through the formation of alkali phosphates. ${ }^{42}$ For biomass with large chlorine and alkali content, utilization of Ca-based additives such as $\mathrm{Ca}(\mathrm{OH})_{2}$ or $\mathrm{CaCO}_{3}$ normally do not greatly influence or can even increase the concentration of alkali chlorides/fine particles in the flue gas. ${ }^{20}$ However, for biomass rich in $\mathrm{P}$ and alkalis, a significant decreasing effect on the fine particle formation may be achieved by using Ca-based additives. ${ }^{33,34}$ In general, with the purpose of minimizing ash related problems in biomass combustion, additives which have a pronounced decreasing effect on the harmful species (e.g., alkali chlorides) in the flue gas are desirable. Besides, an ideal additive is also expected to be cheap and easy to handle and should not significantly influence the fuel combustion behavior and ash utilization.

The aim of the present work was to provide a systematic evaluation of the ash morphology, chemistry, and deposition behavior during dust-firing of straw. In addition, the feasibility of utilizing spent bleaching earth (SBE) as an additive in straw dustfiring was examined, through comparison with kaolinite. The $\mathrm{SBE}$ is a powdery residual product from vegetable-oil production, which is considered to be an applicable additive in straw dustfiring because of the relatively high heating value, cheap price, and the relatively large $\mathrm{Si}$ content. To achieve the objective of this work, dust-firing of straw was performed in an entrained flow reactor (EFR) at different shares of SBE and kaolinite, respectively. The composition of different ash fractions from the experiments was analyzed, and the ash chemistry in dust-firing of straw with and without additives was investigated. With the collection of ash deposits on a probe with controlled conditions, the influence of additives on deposition rate and deposit composition was also examined.

\section{EXPERIMENTAL SECTION}

2.1. Fuel and Additives. The straw used in the present work was a Danish wheat straw, with compositions listed in Table 1 . It is seen that

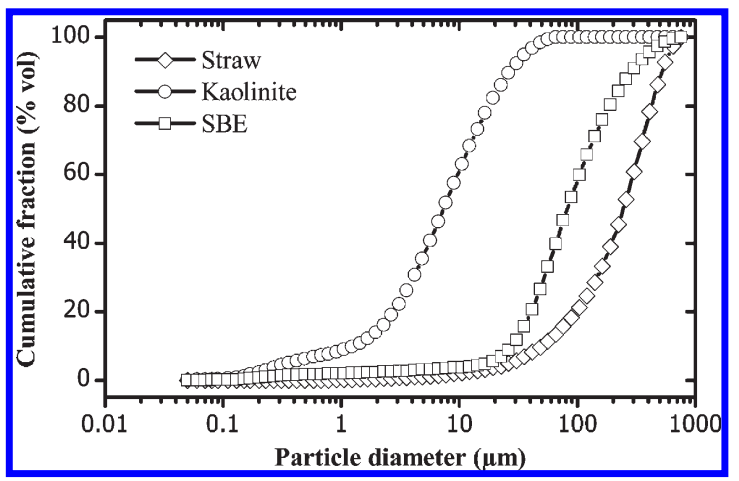

Figure 1. Particle size distribution of the straw, kaolinite, and SBE.

the most abundant inorganic elements in the straw are $\mathrm{Si}, \mathrm{K}, \mathrm{Ca}$, and $\mathrm{Cl}$. Compared to the Danish straw used in other studies, ${ }^{4,17,20,32,43}$ the $\mathrm{Cl}$ content in this straw is relatively low, whereas the K content is comparable.

Bleaching earth refers to clays that are capable of absorbing coloring matter and undesirable residues during the processing of edible oils as well as the production of oleochemicals. ${ }^{44}$ The spent bleaching earth (SBE) used in this work was from a Danish company producing vegetable oil (Aarhus Karlshamn AB). The price of SBE was approximately $40 \mathrm{DKK} /$ GJ, which was considered to be similar to the price of straw in Denmark. ${ }^{45}$ Since the received SBE contained some vegetable oil $(\sim 10 \mathrm{wt} \%)$ which agglomerated the particles, the SBE was dried at $80{ }^{\circ} \mathrm{C}$ for $4 \mathrm{~h}$. The resulting SBE was a mixture of bleaching earth $(\sim 50 \mathrm{wt} \%)$, activated carbon $(\sim 25 \mathrm{wt} \%)$, and cellulose-based filter aid $(\sim 25 \mathrm{wt} \%)$, with the composition listed in Table 1. It can be seen that the SBE has a large ash content, and the ash is dominated by $\mathrm{Si}$. The heating value of SBE is comparable to straw. An additional characteristic of SBE is that the trace element content in SBE is usually negligible. ${ }^{45}$ This is favorable, since the concentration of trace elements is a major limiting factor for utilizing the residue ash from biomass combustion as fertilizer. ${ }^{2}$ The kaolinite used in the present work was a pure compound, with analyzed compositions listed in Table 1. The kaolinite has larger ash, $\mathrm{Al}$, and $\mathrm{Si}$ contents than that of SBE.

In order to facilitate fuel feeding, the straw was ground at an Alpine pin mill. The SBE and kaolinite were received as small particles which did not require further treatment. The particle size distribution of the straw and additives was analyzed by a laser diffraction method with the Malvern Mastersizer 2000 particle size analyzer. The measured particle size distribution is depicted in Figure 1. It is seen that the straw particles have a $d_{50}$ (meaning that 50 volume $\%$ of the particles are below this size) of about $285 \mu \mathrm{m}$. The SBE particles are much smaller than the straw particles, having a $d_{50}$ of about $95 \mu \mathrm{m}$. The kaolinite particles are extremely fine particles, with a $d_{50}$ of approximately $8 \mu \mathrm{m}$.

2.2. Setup. The experiments were carried out in an entrained flow reactor (EFR) which was designed to simulate the combustion conditions of a suspension fired boiler. The setup consists of a gas supply system, a fuel feeding system, a gas preheater, a $2 \mathrm{~m}$ long vertical reactor electrically heated by 7 heating elements, a bottom chamber, a particle and gas extraction system, and a particle deposition system, which simulates deposit formation on superheaters in a boiler. A schematic drawing of the setup is shown in Figure 2, with more detailed descriptions of the reactor available elsewhere. ${ }^{4}$

During the experiments, straw particles or the premixed straw and additive particles were injected into the reactor by the primary air. In order to have a comparable residence time in different experiments, the flow rate of the primary air and total air was maintained at 13 and $95 \mathrm{~N} \mathrm{~L} / \mathrm{min}$, respectively. The feeding rate of the fuel particles was controlled by a gravimetric screw feeder and was adjusted to an excess air ratio of approximately 1.6. This excess air ratio was chosen in order to 
ensure a sufficient burnout in the reactor. After injection, the fuel particles were mixed with the preheated secondary air at the inlet of the vertical reactor and subsequently combusted in the reactor. The temperature of the heating element in the preheater was controlled at $900{ }^{\circ} \mathrm{C}$, and the wall temperature of the vertical reactor was set to $1000-1300{ }^{\circ} \mathrm{C}$ for all of the experiments, similar to the conditions used in previous studies. ${ }^{4,6}$ It should be noted that although the wall temperatures are set to constant values during the experiments and the excess air ratio in different experiments is controlled to be similar, it is difficult to know if the flame temperature is the same in different experiments. However, since the present work is an application oriented research focusing on the general influence of SBE and kaolinite addition on straw dusting-firing, the effect of detailed factors (such as ignition delays, flame temperature, and residence time of different ash particles), which may vary in different experiments, is difficult to assess and is outside the scope of this work. On the other hand, since the air input and the excess air ratio are almost fixed in the experiments and the reactor is electrically heated, it is believed the reactor temperature profile would only change little between the experiments.

After the fuel particles were combusted in the reactor, the bottom ash was collected in the bottom chamber. The flue gas was separated into two fractions. As illustrated in Figure 2, a minor part of the flue gas was drawn to an extraction system through a water-cooled probe. The watercooled probe was placed perpendicular to the direction of the flue gas and the sampling point was located at the center of the reactor tube. The probe had an outer diameter of $6.4 \mathrm{~mm}$ and an inner diameter of $4.4 \mathrm{~mm}$. The flue gas temperature at the sampling point was about $600^{\circ} \mathrm{C}$, which was rapidly cooled to about $100^{\circ} \mathrm{C}$ in the water-cooled probe. It needs to be noted that the significant temperature gradient between the flue gas and the surface of the water cooled probe may induce thermophoresis

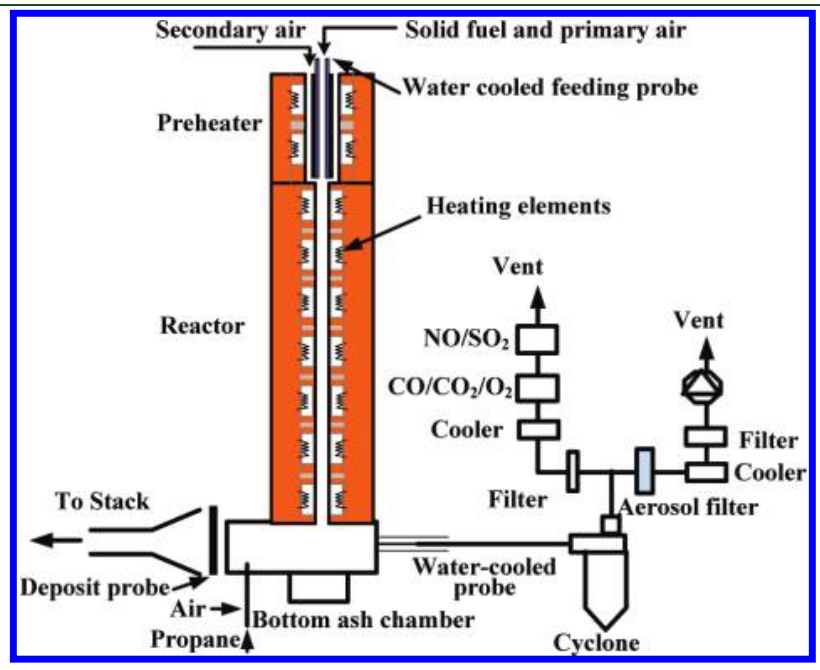

Figure 2. Schematic drawing of the entrained flow reactor. and lead to the deposition of aerosols on the probe surface. These deposited aerosols and other fly ash particles in the cooling probe were collected after the experiment and were considered as part of the cyclone ash. The large fly ash particles passing through the water-cooled probe were collected by a cyclone with a cutoff diameter of $2.5 \mu \mathrm{m}$, and the remaining fine fly ash particles were gathered on an aerosol filter using a polycarbonate membrane with a pore size of $0.1 \mu \mathrm{m}$. The concentration of $\mathrm{CO}, \mathrm{CO}_{2}, \mathrm{O}_{2}, \mathrm{NO}$, and $\mathrm{SO}_{2}$ was measured by two gas analyzers. The remaining flue gas was directed toward a deposit probe. In front of the deposit probe, a propane burner was mounted to control the flue gas temperature to be $750{ }^{\circ} \mathrm{C}$. It should be noted that the flue gas introduced by the propane burner slightly lowered the concentration of fly ash and the vaporized inorganic species in flue gas, thereby influencing the ash deposition rate on the probe. However, since the propane burner was operated at similar conditions at different experiments, the obtained ash deposition results would still be comparable. One should be aware that the "ash deposition" in this paper is not restricted to the deposition of solid ash particles but rather referring to the deposition of the ash forming species through different mechanisms such as inertial impaction, thermophoresis, and condensation of inorganic vapors. The air-cooled deposit probe was made of stainless steel, with an outer diameter of $1 \mathrm{~cm}$ and a length of $10 \mathrm{~cm}$. The probe was placed in front of the exit slit of bottom chamber which has a size of $4 \times 8 \mathrm{~cm}^{2}$. By adjustment of the temperature of the air preheater and the heating tape connected to the probe, the surface temperature of the deposit probe was controlled to be around $470{ }^{\circ} \mathrm{C}$ during the experiments. The temperature was chosen according to the typical superheater temperature in a straw dust-firing plant. ${ }^{2}$

The duration of an experiment was $90 \mathrm{~min}$. In order to achieve a stable combustion condition, the reactor was preheated to operational temperatures and kept overnight, and the fuel injection began $40 \mathrm{~min}$ prior to the start of an experiment. After the experiment, the deposits on the probe, the ash from the extraction tubes, cyclone, aerosol filter, and bottom chamber were collected, weighed, and preserved for chemical analysis. In order to minimize the influence of deposit built up inside the reactor, the reactor was heated to $1400{ }^{\circ} \mathrm{C}$ for $20 \mathrm{~h}$ after every experiment to perform hightemperature cleaning.

2.3. Experimental Matrix. The experimental matrix is shown in Table 2. It is seen that the excess air ratio in different experiments is maintained around 1.6. In addition to pure straw combustion, the straw has been cofired with a different mass share of kaolinite or SBE. The added SBE was $10 \mathrm{wt} \%$ and $20 \mathrm{wt} \%$, respectively. The addition kaolinite was chosen to be $5 \mathrm{wt} \%$ and $10 \mathrm{wt} \%$, respectively, in order to perform the experiments at similar $\mathrm{K} /(\mathrm{Al}+\mathrm{Si})$ molar ratios as that of $\mathrm{SBE}$ addition.

2.4. Ash/Deposit Analysis. The fuel, ash, and deposit samples from the experiments were analyzed at the Enstedværket Laboratory, DONG Energy A/S. The content of $\mathrm{Al}, \mathrm{Ca}, \mathrm{Fe}, \mathrm{K}, \mathrm{Mg}, \mathrm{Na}, \mathrm{P}, \mathrm{Si}, \mathrm{Ti}, \mathrm{S}$, and $\mathrm{Cl}$ in the different fuels and ash fractions were analyzed by inductively coupled plasma optical emission spectrometry (ICP-OES). The water-soluble $\mathrm{K}, \mathrm{Na}, \mathrm{Cl}$, and $\mathrm{S}$ content in the cyclone ash and deposit was analyzed by ICP-OES/IC. For this analysis, the ash/deposit

Table 2. Experimental Matrix and Conditions

\begin{tabular}{|c|c|c|c|c|c|c|}
\hline \multirow[b]{2}{*}{ experiment no. } & \multirow[b]{2}{*}{ fuel } & \multirow[b]{2}{*}{ excess air ratio } & \multicolumn{4}{|c|}{ molar ratios in fuel } \\
\hline & & & $\mathrm{K} / \mathrm{Si}$ & $\mathrm{K} /(\mathrm{Al}+\mathrm{Si})$ & $\mathrm{K} / \mathrm{Cl}$ & $\mathrm{K} /(\mathrm{Cl}+2 \mathrm{~S})$ \\
\hline 1 & straw $^{a}$ & 1.62 & 0.42 & 0.42 & 4.08 & 1.90 \\
\hline 2 & straw +5 wt $\%$ kaolinite & 1.62 & 0.25 & 0.17 & 4.51 & 2.10 \\
\hline 3 & straw $+10 \mathrm{wt} \%$ kaolinite & 1.62 & 0.18 & 0.11 & 4.99 & 2.32 \\
\hline 4 & straw +10 wt $\% \mathrm{SBE}^{a}$ & 1.58 & 0.26 & 0.17 & 4.54 & 1.88 \\
\hline 5 & straw $+20 w t \%$ SBE & 1.57 & 0.19 & 0.10 & 5.11 & 1.85 \\
\hline
\end{tabular}

${ }^{a}$ Repetition experiments have been performed. 
sample was dissolved in ultrapure water at $120^{\circ} \mathrm{C}$ for $1 \mathrm{~h}$, and then the solution was filtered and analyzed by ICP-OES/IC. Besides the bulk chemical analysis, the typical morphology and composition of the fly ash particles from the experiments were characterized by using scanning electron microscopy and dispersive X-ray spectroscopy (SEM-EDS).

\section{RESULTS AND DISCUSSION}

3.1. Ash Behavior during Straw Dust-Firing. 3.1.1. Mass Balance. The ash and elemental mass balance in dust-firing of straw has been calculated based on the fuel and ash composition, the fuel feeding rate, the flue gas composition, and the amount of the collected ash and the corresponding flue gas flow rate (see details in the Supporting Information). The results are depicted in Figure 3. It can be seen that the overall ash balance is around $95 \%$. Approximately $20 \%$ of the fuel ash is partitioned to bottom ash, with the remaining being fly ash particles. The percentage of the filter ash and cyclone ash in fly ash is about $15 \%$ and $85 \%$, respectively. The ash distribution indicates that the fly ash concentration in the flue gas is significantly increased in dustfiring of straw, compared to the grate-firing of straw where only about $10-20 \%$ of the fuel ash is partitioned to the fly ash. ${ }^{46}$ The increased fly ash concentration may lead to more ash deposition in the superheater region. In addition, a significant fraction $(\sim 15 \%)$ of the fly ash is found to be present as fine particles smaller than $2.5 \mu \mathrm{m}$, which is considerably higher than the fraction during pulverized coal combustion in the same reactor $(\sim 8 \%)^{6}$

Similar to the ash balance, the mass balance of the major inorganic elements is mostly above $90 \%$, except for $\mathrm{Al}, \mathrm{Na}$, and $\mathrm{K}$. The mass balance of $\mathrm{Al}$ is much higher than $100 \%$. This is

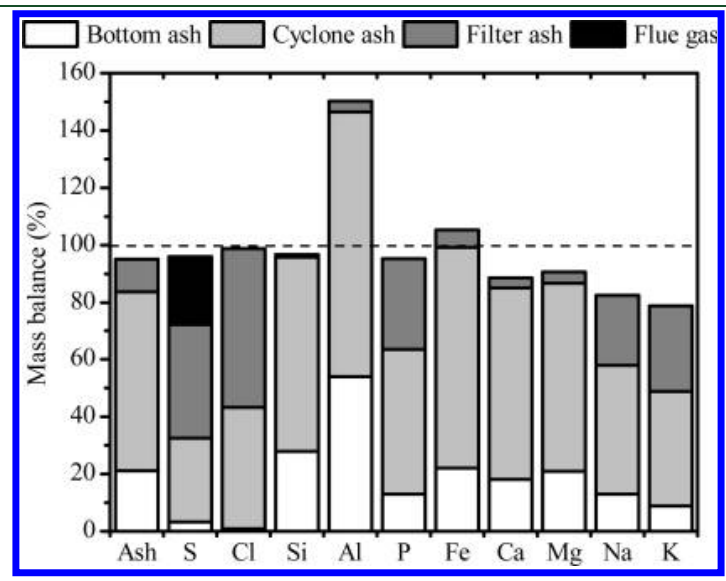

Figure 3. Ash and elemental mass balance during straw dust-firing. probably because of the $\mathrm{Al}$ content in straw is very small (see Table 1), thus the influence of analysis uncertainties may be significant. The mass balance of $\mathrm{Na}$ and $\mathrm{K}$ is around $80 \%$, implying that part of the $\mathrm{Na}$ and $\mathrm{K}$ in straw may have been deposited on the reactor tube during the experiment. This hypothesis is supported by the deposits observed on the reactor tube after the experiment. One the other hand, although the collection of ash particles in the sampling system has been carried out carefully, a fraction of ash particles may still not be collected, particularly for the aerosols deposited in the water-cooled extraction probe via thermophoresis.

The partitioning of inorganic element to different ash fractions is illustrated in Figure 3. It is seen that approximately $99 \%$ of the $\mathrm{Cl}$ in straw is found in ash, suggesting the presence of $\mathrm{HCl}(\mathrm{g})$ in the flue gas may be negligible in this experiment. The observed significant $\mathrm{Cl}$ retention in ash is probably linked to the high $\mathrm{K} / \mathrm{Cl}$ molar ratio in the straw $(>4)$, which may favor the formation of $\mathrm{KCl}$. The $\mathrm{Cl}$ distribution also indicates that $\mathrm{Cl}$ is significantly enriched in the filter ash, whereas the presence of $\mathrm{Cl}$ is negligible in the bottom ash. For the $\mathrm{S}$ distribution, it seems that about $70 \%$ of the $\mathrm{S}$ is retained in the ash, with the remaining being gaseous $\mathrm{S}$ (mainly as $\mathrm{SO}_{2}$ ) in the flue gas. Similar to the $\mathrm{Cl}$ distribution, a significant enrichment of $S$ is found in the filter ash, while the partitioning of $S$ to the bottom ash is minor. The distribution of the other inorganic elements generally represents the ash partitioning. However, for elements such as $\mathrm{P}, \mathrm{Na}$ and $\mathrm{K}$, a slight enrichment in the filter ash is noticeable.

3.1.2. Typical Fly Ash Morphology and Composition. SEMEDS has been used to characterize the morphology and composition of the fly ash particles from straw dust-firing. Figure 4 illustrates the observed typical fly ash morphologies (the results are considered to be representative for a large number of analysis performed), with the corresponding spot-analysis compositions given in Figure 5. It is generally found that the cyclone ash from straw dust-firing is dominated by molten or partially molten spherical particles. The large spherical particles, as illustrated in Figure $4 b$, often consist of K-silicates or K-Ca-silicates (see the compositions of spots 1 and 4 in Figure 5b). In addition, there are some relatively smaller spherical particles which are rich in $\mathrm{Si}, \mathrm{P}$, $\mathrm{K}$, and $\mathrm{Ca}$ (see spots 2 and 3 in Figure 4a and Figure 5a). Besides the spherical particles, some flake-shaped particles are also observed in the cyclone ash (see spots 1 and 5 in Figure 4a). These particles typically have a high Si content (>90 wt \%), which may explain the appearance of the particles, as the melting temperature of silicon oxide is considerably higher than that of K-silicates or K-Ca-silicates. ${ }^{47}$

Compared to the cyclone ash shown in parts a and $\mathrm{b}$ of Figure 4, the morphology of the filter ash shown in Figure $4 \mathrm{c}$ is significantly different. The filter ash primarily consists of small

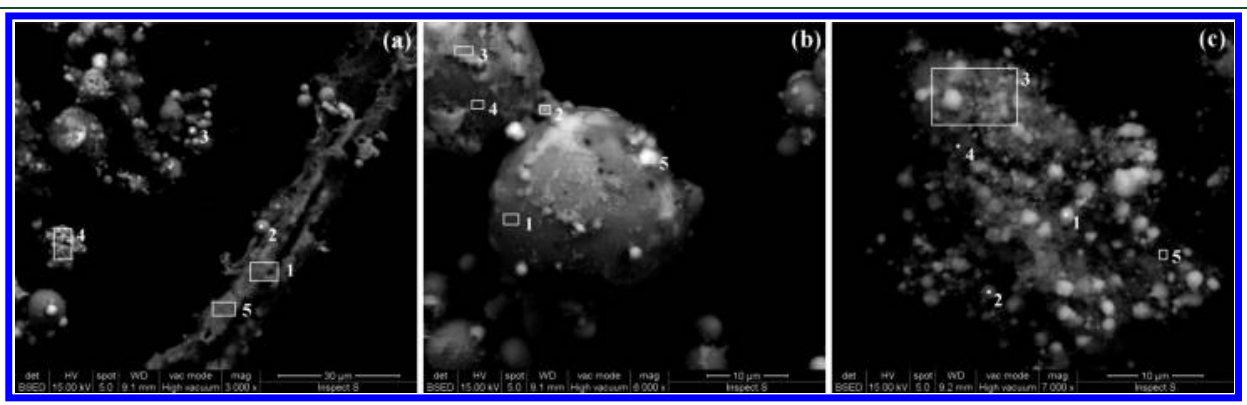

Figure 4. SEM pictures of the fly ash particles from dust-firing of straw, parts a and b are from the cyclone ash and part $\mathrm{c}$ is from the filter ash. 


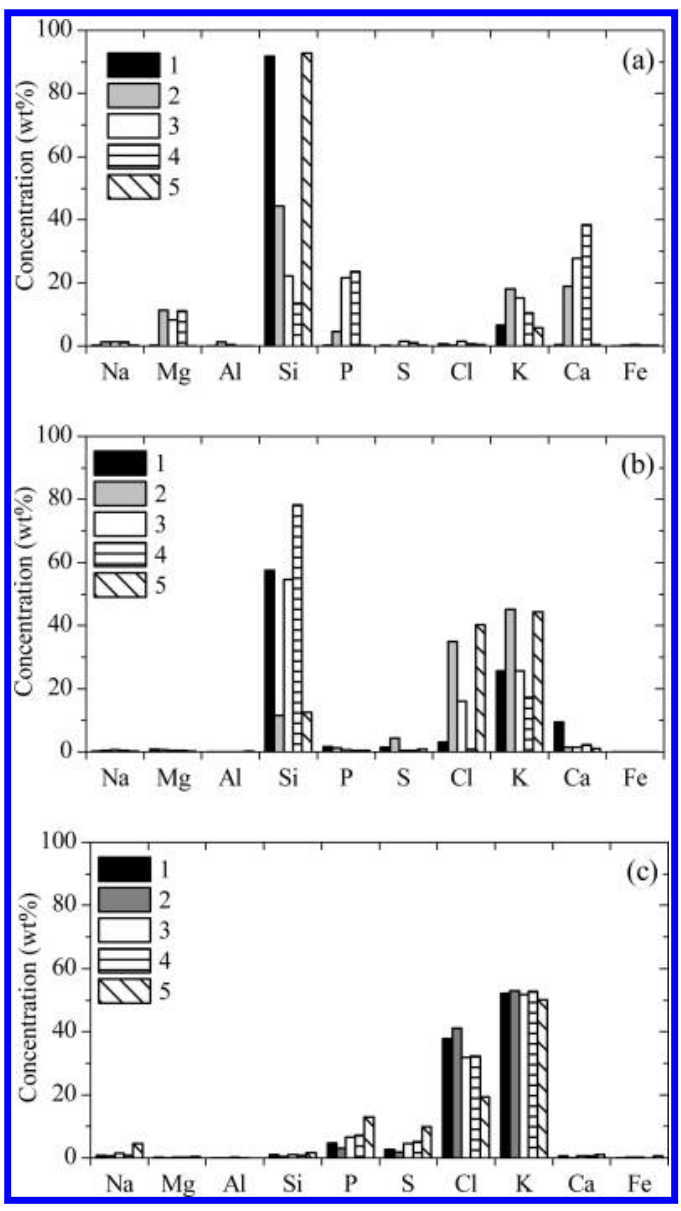

Figure 5. Inorganic compositions (i.e., the $\mathrm{O}$ and $\mathrm{C}$ content is neglected) of the spots shown in Figure 4.

and irregularly shaped particles, which are likely formed from nucleation, condensation, and aggregation of the vaporized inorganic species. The large particles seen in Figure $4 c$ are probably a result of particle impaction in the filter, as the composition of the large particles is quite similar to that of small nucleates. As shown in Figure 5c, the composition of the filter ash is dominated by vaporized inorganic elements such as $\mathrm{K}, \mathrm{Cl}, \mathrm{P}$, and $\mathrm{S}$, which supports its formation mechanism. Besides conversion to filter ash, some of the vaporized inorganic species may also condense or attach to the existing ash particles, as illustrated by spots 2, 3, and 5 in Figures $4 \mathrm{~b}$ and $5 \mathrm{~b}$.

3.1.3. Bulk Ash Composition. Figure 6 depicts the bulk composition of the bottom ash, the cyclone ash, and the filter ash collected from straw dust-firing. For comparison, the fuel ash composition, which is calculated from the straw properties, is also shown. It can be seen that the bottom ash from straw dust-firing is dominated by $\mathrm{Si}, \mathrm{K}$, and $\mathrm{Ca}$. Compared with the fuel ash, the bottom ash is slightly enriched in Si but depleted in Ca and $\mathrm{K}$. The presence of $\mathrm{S}$ and $\mathrm{Cl}$ is almost negligible in the bottom ash, which may be explained by the high volatility of $\mathrm{S}$ and $\mathrm{Cl}$ during straw combustion. ${ }^{12}$ The cyclone ash composition generally represents the fuel ash composition. Compared to the fuel ash, the volatile inorganic elements such as $\mathrm{S}, \mathrm{Cl}, \mathrm{P}, \mathrm{Na}$, and $\mathrm{K}$ are slightly depleted in the cyclone ash, whereas the nonvolatile elements such as $\mathrm{Si}, \mathrm{Al}, \mathrm{Fe}, \mathrm{Ca}$, and $\mathrm{Mg}$ are slightly increased. The filter ash primarily consists of the volatile inorganic elements $\mathrm{K}$, $\mathrm{Cl}, \mathrm{S}$, and $\mathrm{P}$, which contribute to more than $90 \%$ of the inorganic

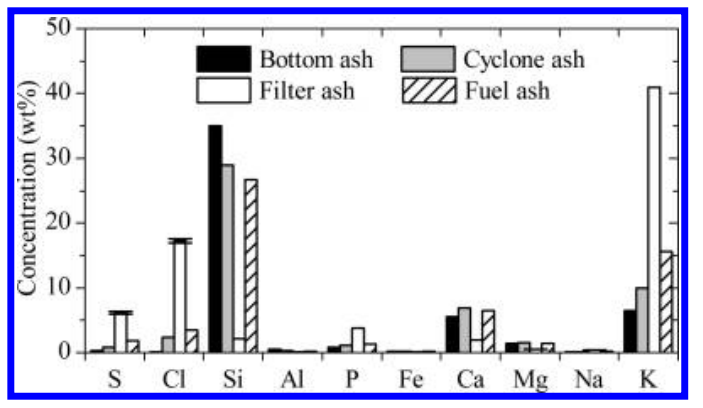

Figure 6. Bulk composition of the bottom ash, cyclone ash, filter ash, and fuel ash during straw dust-firing; the error bars on the filter ash composition show the deviations of two repetition experiments.

elements in the filter ash. The composition of the filter ash obtained from two repeating experiments is almost identical, which supports the reliability of the measurements. Both the composition and the morphology of the filter ash suggest that during straw-dust firing, the ash particles smaller than $2.5 \mu \mathrm{m}$ are predominantly generated from vaporized inorganic elements. Since the composition of the filter ash obtained in this work is close to the composition of the aerosols from grate-firing of straw, ${ }^{21,22}$ the particle formation mechanism in the two cases is presumably quite similar. During grate-firing of straw, the formation of aerosols is considered to be initiated by the homogeneous nucleation of $\mathrm{K}_{2} \mathrm{SO}_{4}$, followed by the condensation of $\mathrm{KCl}$ and $\mathrm{K}_{2} \mathrm{SO}_{4}$ as well as coagulation. ${ }^{48,49}$ This mechanism may greatly contribute to the formation of the filter ash obtained in this work. On the other hand, a small fraction of the filter ash, which contains a relatively large content of the nonvolatile elements such as $\mathrm{Si}$ and $\mathrm{Al}$, may be originating from the small mineral particles presented in the original straw or generated by the fragmentation of included or excluded minerals. In pulverized coal combustion, the fragmentation mechanism is found to be an important PM2.5 formation mechanism. ${ }^{50}$ However, in straw dust-firing, the contribution of this mechanism is limited to the PM2.5 formation, as indicated by the composition of the collected filter ash.

Besides the bulk ash composition, a useful parameter to evaluate the deposition/corrosion potential of fly ash from straw dust-firing is the water-soluble alkali concentration. ${ }^{4}$ The watersoluble alkalis, such as alkali chlorides, are normally more corrosive than water insoluble alkalis such as alkali silicates. ${ }^{16,18}$ In the present work, the water-soluble $\mathrm{K}$ and $\mathrm{Na}$ content in the cyclone ash has been analyzed, showing that about $53 \%$ of the $\mathrm{K}$ and $41 \%$ of the $\mathrm{Na}$ in the cyclone ash are water-soluble. Besides, since the filter ash is dominated by volatile species such as $\mathrm{Cl}, \mathrm{S}, \mathrm{P}$, and $\mathrm{K}$ which normally form water-soluble species, it is reasonable to assume that the alkalis in the filter ash are totally water-soluble. With this assumption, the water-soluble $\mathrm{K}$ and $\mathrm{Na}$ content in the fly ash can be calculated based on the ash composition shown in Figure 6 and the mass balance given in Figure 3. The calculation reveals that about $73 \%$ of $\mathrm{K}$ and $62 \%$ of $\mathrm{Na}$ in the fly ash from straw dust-firing are water-soluble. The molar ratio of the (watersoluble $\mathrm{K}+\mathrm{Na}) /(\mathrm{Cl}+2 \mathrm{~S}+\mathrm{P})$ in the fly ash is about 0.98 , suggesting the water-soluble $\mathrm{K}$ and $\mathrm{Na}$ in the fly ash are most likely present as chlorides, sulfates, and phosphates. The molar ratio of $\mathrm{Cl} /$ (water-soluble $\mathrm{K}+\mathrm{Na}$ ) is about 0.46 , indicating that approximately $46 \%$ of the water-soluble alkalis in the fly ash is alkali chlorides. 


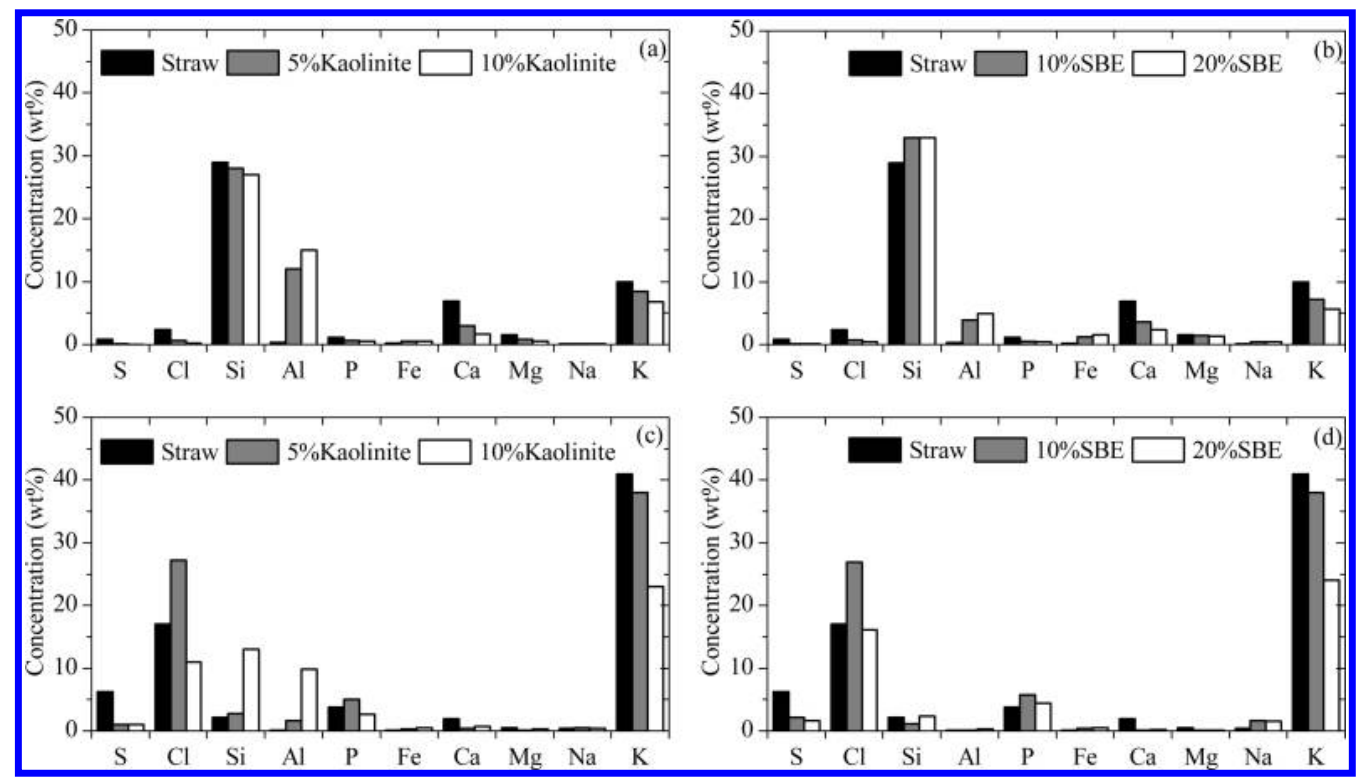

Figure 7. (a) Influence of kaolinite addition on cyclone ash composition, (b) influence of SBE addition on cyclone ash composition, (c) influence of kaolinite addition on filter ash composition, and (d) influence of SBE addition on filter ash composition.

3.2. Effect of Additives on Straw Dust-Firing. 3.2.1. Ash Chemistry. Figure 7 shows the influence of kaolinite and SBE addition on the cyclone and filter ash composition during straw dust-firing. It is seen that the variation of the cyclone ash composition generally reflects the ash composition change in the fuel mixture. With the addition of kaolinite, the $\mathrm{Al}$ content in the cyclone ash is increased significantly, whereas the content of $\mathrm{S}, \mathrm{Cl}, \mathrm{Ca}, \mathrm{P}$, and $\mathrm{K}$ is reduced because of the dilution effect. The decreasing effect on the $\mathrm{S}$ and $\mathrm{Cl}$ may be also associated with the chemical reactions between kaolinite and the vaporized $\mathrm{S} / \mathrm{Cl}$ species, which release $\mathrm{SO}_{2} / \mathrm{HCl}$ to the flue gas. Similar to kaolinite, the addition of SBE also reduces the content of $\mathrm{S}, \mathrm{Cl}$, $\mathrm{Ca}, \mathrm{P}$, and $\mathrm{K}$ in the cyclone ash. The $\mathrm{Si}$ and $\mathrm{Al}$ content in the cyclone ash is increased with SBE addition, which reflects the difference in the ash composition of SBE and straw.

Compared to the cyclone ash, the influence of kaolinite and SBE addition on the filter ash composition shows some different tendencies. With the addition of $5 \mathrm{wt} \%$ kaolinite, the $S$ content in the filter ash is decreased compared to pure straw combustion, whereas the $\mathrm{Cl}$ content is increased. A similar tendency is observed with the addition of $10 \mathrm{wt} \%$ SBE. However, the increased $\mathrm{Cl}$ content does not necessarily mean that the formation of $\mathrm{KCl}$ is increased with the addition of $5 \mathrm{wt} \%$ kaolinite or 10 wt \% SBE. During dedicated straw combustion, the collected filter ash contributes to about $10 \%$ of the fuel ash (see Figure 3), while this contribution becomes about $2.5 \%$ and $1.9 \%$, respectively, during the addition of $5 \mathrm{wt} \%$ and $10 \mathrm{wt} \% \mathrm{SBE}$, which is significantly beyond the dilution effect caused by these two additives. This indicates that the formation of $\mathrm{KCl}$ is actually decreased with the addition of $5 \mathrm{wt} \%$ kaolin or $10 \mathrm{wt} \%$ SBE. On the other hand, with the addition of $10 \%$ kaolinite, both the $\mathrm{Cl}$ and $\mathrm{K}$ content in the filter ash is decreased compared to $5 \%$ kaolinite addition, while the $\mathrm{Si}$ and $\mathrm{Al}$ content is increased. This suggests that a fraction of the kaolinite particles is partitioned to filter ash under this condition. The molar ratio of $(\mathrm{K}+\mathrm{Na})$ / $(\mathrm{Cl}+2 \mathrm{~S}+\mathrm{P})$ in the filter ash from $10 \mathrm{wt} \%$ kaolinite addition is about 1.3, implying that part of the $\mathrm{K}$ and $\mathrm{Na}$ (about 25\%) in the filter ash is probably presented as $\mathrm{Na}$ - or K-aluminosilicates.
Compared to $10 \mathrm{wt} \%$ SBE addition, a considerable decrease of the $\mathrm{Cl}$ and $\mathrm{K}$ content is observed in the filter ash collected from $20 \mathrm{wt} \%$ SBE addition. Since an increase of other inorganic elements is not observed, it is likely that the decrease of $\mathrm{Cl}$ and $\mathrm{K}$ content is linked to an increased formation of soot/small residual carbon under this condition. For other experiments, the contribution of inorganic elements/oxides to the formation of the filter ash is generally rather consistent.

The results shown in Figure 7 indicate that the composition of fly ash may be both affected by the dilution effect of the additives and chemical interactions. In order to better evaluate the chemical effect of kaolinite and SBE addition on the $S$ partitioning, the percentage of $\mathrm{S}$ in the fuel/fuel mixture emitted as $\mathrm{SO}_{2}$ is calculated based on the measured $\mathrm{SO}_{2}$ concentration in the flue gas. From Figure $8 \mathrm{a}$, it can be seen that both the addition of kaolinite and $\mathrm{SBE}$ increases the conversion of fuel $\mathrm{S}$ to $\mathrm{SO}_{2}$. Since the presence of $S$ is found to be negligible in the kaolinite (see Table 1), the results imply that the formation of alkali sulfates is inhibited. The inhibiting effect of kaolinite on alkali sulfate formation has been reported in other work. ${ }^{51}$ It is likely that the added kaolinite has reacted with the $\mathrm{KOH} / \mathrm{KCl}$ released from straw combustion, ${ }^{12}$ thereby reduced the sulphation reaction between gaseous alkali and $\mathrm{SO}_{2} / \mathrm{SO}_{3}$. In addition, the alkali sulfate may react with kaolinite directly and release $\mathrm{SO}_{2}{ }^{52}$ However, the formation of alkali sulfate in straw combustion is usually thermodynamically favored at temperatures lower than $1000{ }^{\circ} \mathrm{C} .{ }^{53-55}$ In the EFR, the residence time in the temperature range of $1300-600{ }^{\circ} \mathrm{C}$ (sampling point) is rather short (on the order of $0.1 \mathrm{~s}$ ). This indicates that the direct reaction between alkali sulfate and kaolinite probably is not important for the increased $\mathrm{SO}_{2}$ formation observed in the present work. Therefore, the primary mechanism for the increased $\mathrm{SO}_{2}$ formation is likely the reaction between the added kaolinite particles and the vaporized $\mathrm{KOH} / \mathrm{KCl}$. For different shares of kaolinite, the effect is particularly pronounced with the addition of 5 wt \% kaolinite, as compared to pure straw combustion. However, when the kaolinite share is increased from $5 \mathrm{wt} \%$ to $10 \mathrm{wt} \%$, the decreasing effect is only slightly promoted. 

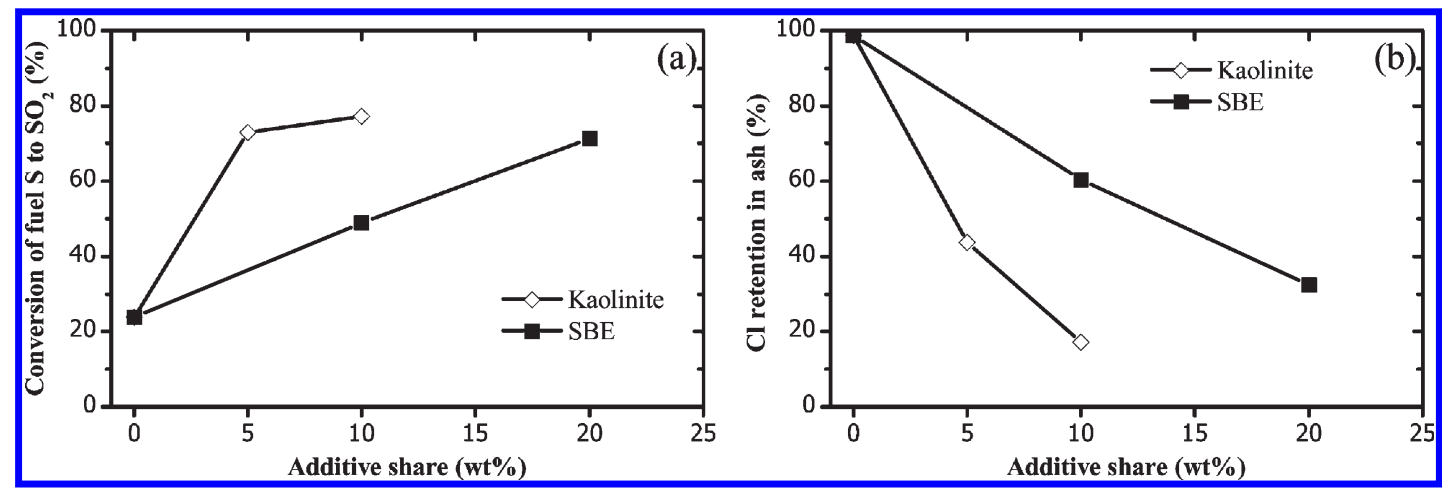

Figure 8. (a) Conversion of fuel $\mathrm{S}$ to $\mathrm{SO}_{2}$ (\%) during the addition of kaolinite or $\mathrm{SBE}$ and (b) Cl retention in ash (\%) during the addition of kaolinite or SBE.
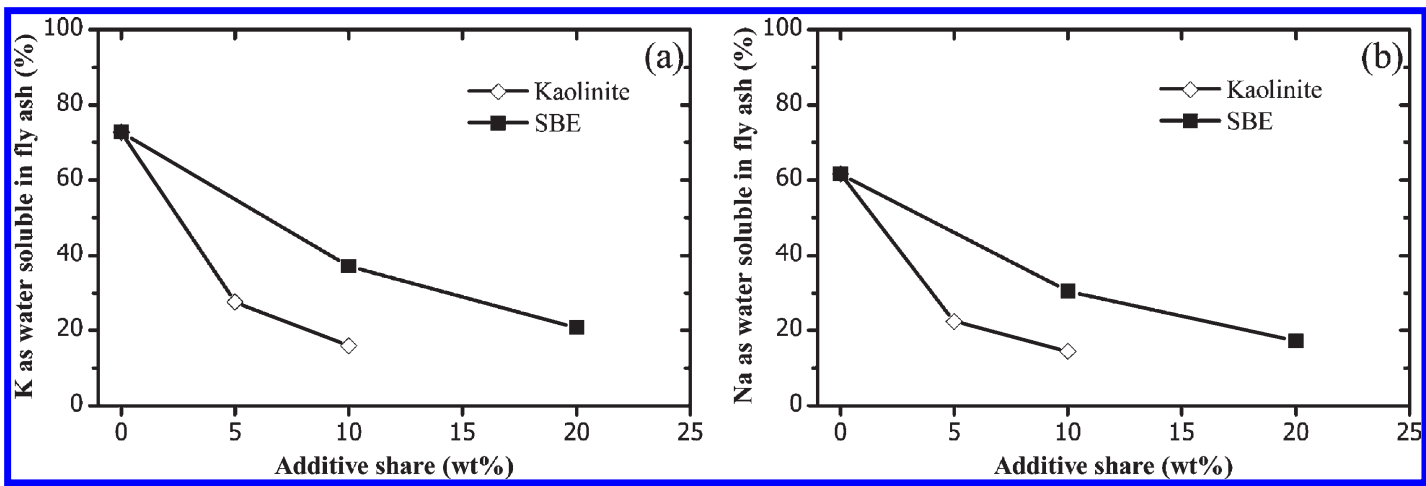

Figure 9. (a) Percentage of $\mathrm{K}$ present as the water-soluble form in fly ash and (b) percentage of Na present as the water-soluble form in fly ash.

Similar to kaolinite, the addition of SBE also increases the formation of $\mathrm{SO}_{2}$. A possible reason is that part of the $\mathrm{Si}$ and $\mathrm{Al}$ in SBE reacts with the gaseous $\mathrm{KOH} / \mathrm{KCl}$ released from straw combustion, forming stable K-silicates or K-aluminosilicates. Such reactions have been reported to be thermodynamically feasible, when straw is cofired with a fuel with high $\mathrm{Si}$ and $\mathrm{Al}$ content. ${ }^{4,53,56}$ As shown in Figure 8a, the conversion of fuel $\mathrm{S}$ to $\mathrm{SO}_{2}$ is increased approximately from $24 \%$ to $49 \%$, with the addition of $10 \mathrm{wt} \% \mathrm{SBE}$. When the addition of SBE is increased to $20 \mathrm{wt} \%$, the conversion of fuel $\mathrm{S}$ to $\mathrm{SO}_{2}$ is increased further to about $71 \%$. Through the comparison of the results from kaolinite and SBE addition, it appears that the effect of kaolinite is more significant than that of SBE, when applying the same molar ratio of $\mathrm{K} /(\mathrm{Al}+\mathrm{Si})$ in the fuel mixture, such as $5 \mathrm{wt} \%$ kaolinite versus 10 wt \% SBE or 10 wt \% kaolinite versus 20 wt \% SBE (see Table 2). However, when the molar ratio of $\mathrm{K} /(\mathrm{Al}+\mathrm{Si})$ is around 0.10 , i.e., $10 \mathrm{wt} \%$ kaolinite or $20 \mathrm{wt} \% \mathrm{SBE}$ addition, the difference between the two additives becomes minor, as illustrated in Figure 8a.

In order to investigate the impact of kaolinite and $\mathrm{SBE}$ on $\mathrm{Cl}$ partitioning, the percentage of fuel $\mathrm{Cl}$ retention in the ash is calculated for different experiments through a mass balance calculation. As shown in Figure $8 \mathrm{~b}$, the $\mathrm{Cl}$ retention in ash is reduced significantly with the addition of kaolinite/SBE. The results imply that a fraction of the alkali chlorides formed during straw combustion has reacted with the injected kaolinite/SBE particles and releases the $\mathrm{Cl}$ as gaseous $\mathrm{HCl}$. The mechanism of the reactions between alkali chlorides and kaolinite has been studied extensively. ${ }^{35-39}$ The results of the present work show that the addition of $5 \mathrm{wt} \%$ and $10 \mathrm{wt} \%$ kaolinite during dustfiring of straw decreases the $\mathrm{Cl}$ retention in ash by approximately
$55 \%$ and $82 \%$, respectively. Compared to kaolinite, the effect of $\mathrm{SBE}$ is less pronounced, when the molar ratio of $\mathrm{K} /(\mathrm{Al}+\mathrm{Si})$ is similar in the fuel mixture. With the addition of $10 \mathrm{wt} \%$ and 20 wt \% SBE, the $\mathrm{Cl}$ retention in ash during straw dust-firing is reduced by about $39 \%$ and $67 \%$, respectively. The observed relatively lower reactivity of SBE may be linked both to the physical characteristics and the surface reaction kinetics of kaolinite and SBE. According to the particle size distribution shown in Figure 1, the kaolinite particles are much smaller than the SBE particles. Thus, the kaolinite particles likely have larger specific surface area and less transport limitations than the SBE particles, which are favorable for gas-solid reactions. Besides, the surface reaction rate between the gaseous alkali and kaolinite may be greater than that of SBE. It has been reported that the surface reaction rate of kaolinite was much higher than that of silicon oxide, when reacting with alkali chlorides. ${ }^{37,57,58}$ Since the $\mathrm{SBE}$ used in the present work is dominated by $\mathrm{Si}$, it is possible that the surface reaction rate between SBE and the alkali species is slower than that of kaolinite.

The influence of kaolinite and SBE addition on the partitioning of alkali species is assessed by calculating the fraction of water-soluble $\mathrm{K}$ and $\mathrm{Na}$ in the fly ash. The calculation is based on the analyzed water-soluble alkali content in cyclone ash and the assumption that the alkali species in the filter ash are fully watersoluble. The results are present in Figure 9. It can be seen that the addition of kaolinite and SBE both reduce the percentage of $\mathrm{K} / \mathrm{Na}$ present as the water-soluble form in fly ash. This indicates that the formation of water insoluble alkalis, such as alkali aluminosilicates or alkali silicates, is promoted by kaolinite and SBE addition. With the addition of 5 wt $\%$ and 10 wt \% kaolinite, the percentage of $\mathrm{K}$ present as the water-soluble form in fly ash is 


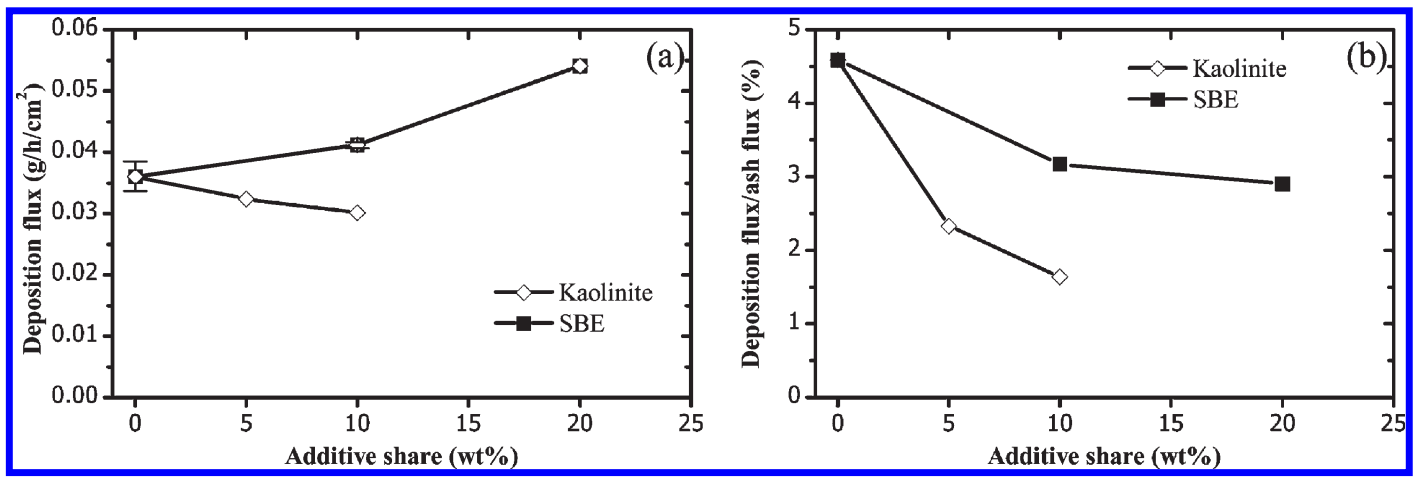

Figure 10. (a) Deposition flux (gram/hour/centimeter squared) during the EFR experiments with kaolinite and SBE addition (the error bars indicate the deviations of two repetition experiments) and (b) deposition flux/ash flux (percent) during the EFR experiments with kaolinite and SBE addition.

reduced by approximately $62 \%$ and $78 \%$, respectively, in comparison with that of pure straw combustion. With the addition of 10 wt \% and 20 wt \% SBE, the percentage of water-soluble $\mathrm{K}$ present in the fly ash is decreased by about $49 \%$ and $71 \%$, respectively. At similar molar ratios of $\mathrm{K} /(\mathrm{Al}+\mathrm{Si})$ in the fuel mixture, the decreasing effect of kaolinite is more significant than that of SBE, which is conceivably linked to the different physical characteristics and surface reaction kinetics of the two additives, as discussed previously. On the other hand, the decreasing effect of kaolinite and SBE addition on the percentage of water-soluble $\mathrm{K}$ may be partly related to the $\mathrm{K}$ present in kaolinite and SBE, which can be rather stable and difficult to vaporize during combustion. For $5 \mathrm{wt} \%$ kaolinite or $10 \mathrm{wt} \%$ SBE addition, the $\mathrm{K}$ in the additive may at a maximum contribute to $10 \%$ of the total $\mathrm{K}$ in fly ash. This implies that chemical reactions would still play a dominant role on the reduction of water-soluble $\mathrm{K}$ under these conditions. However, for $10 \mathrm{wt} \%$ kaolinite or $20 \mathrm{wt} \% \mathrm{SBE}$ addition, the $\mathrm{K}$ in the additives may contribute at a maximum $20 \%$ of the $\mathrm{K}$ in fly ash. Thus the observed further reduction on water-soluble $\mathrm{K}$, when the addition of kaolinite is increased from $5 \mathrm{wt} \%$ to $10 \mathrm{wt} \%$ (or the addition of SBE is increased from $10 \mathrm{wt} \%$ to $20 \mathrm{wt} \%$ ), may be primarily due to the stable $\mathrm{K}$ presented in the kaolinite/SBE, rather than the promoted chemical reactions with straw K. In order to interpret the results shown in Figure 9 better, a detailed analysis of the association and release of K in SBE/kaolinite is needed, which is outside the scope of this work.

The behavior of $\mathrm{Na}$ is quite similar to that of $\mathrm{K}$. However, the percentage of Na present in the water-soluble form is generally lower than that of $\mathrm{K}$. This may imply that the formation of $\mathrm{Na}$ aluminosilicates or silicates may be more favorable than that of $\mathrm{K}$, which seems to be in agreement with the observations in the literature. ${ }^{6,59}$ On the other hand, as shown in Table 1, the SBE has a much higher $\mathrm{Na}$ content than that of straw, which can contribute to about $90 \%$ of the $\mathrm{Na}$ in the fuel mixture during $20 \mathrm{wt} \%$ SBE addition. Thus the observed behavior of watersoluble Na during SBE addition may be greatly influenced by the release of $\mathrm{Na}$ from $\mathrm{SBE}$, which requires further investigations. For kaolinite addition, the $\mathrm{Na}$ in kaolinite would not play a significant role, thus the observed results are mainly attributed to chemical reactions.

One should be aware that the results shown in Figure 9 are obtained by assuming all of the alkali in filter ash is water-soluble. This assumption may not be appropriate for $10 \mathrm{wt} \%$ kaolinite addition, as indicated by the filter composition shown in Figure 7. As mentioned previously, the $\mathrm{Na}$-/K-aluminosilicates may contribute to $25 \%$ of the alkali in the filter ash under this condition.
Therefore, the actual amount of water-soluble alkali during $10 \mathrm{wt} \%$ kaolinite would probably be lower than that shown in Figure 9.

In general, the results present in Figures 8 and 9 demonstrate that the injected SBE particles have reacted with the gaseous alkali released from straw combustion, resulting in a reduced $\mathrm{Cl}$ retention in the ash, increased $\mathrm{SO}_{2}$ emission, and decreased formation of water-soluble alkalis. According to the $\mathrm{Cl}$ retention in the ash shown in Figure $8 \mathrm{~b}$, it seems that the addition of 10 wt \% and 20 wt \% SBE could reduce the alkali chloride formation in straw dust-firing by about $39 \%$ and $67 \%$, respectively. Although the effect of SBE addition is slightly less significant, it is still comparable to the effect of kaolinite addition at a similar molar ratio of $\mathrm{K} /(\mathrm{Al}+\mathrm{Si})$ in the fuel mixture.

3.2.2. Ash Deposition. In order to evaluate the influence of the additives on deposit formation in the convective part of a straw dust-firing boiler, deposits are collected during the EFR experiments by using an air-cooled deposit probe. The deposition flux obtained from the experiments is shown in Figure 10a. It can be seen that the deposition flux increases with the addition of SBE. This is probably linked to the high ash content in the SBE, which has significantly increased the ash flux toward the probe. For kaolinite addition, the deposition flux is decreased compared to pure straw combustion. The deviations of the deposition flux obtained from two repetition experiments during pure straw combustion and the addition of $10 \mathrm{wt} \% \mathrm{SBE}$ is shown in Figure 10a, indicating that the experimental uncertainties on the deposit formation are relatively small.

The deposition flux is divided by the calculated ash flux toward the probe in order to calculate the relative deposit flux. The parameter deposition flux/ash flux (\%) is used to evaluate the deposition propensity of the fly ash. As shown in Figure 10b, the addition of SBE and kaolinite both reduce the ash deposition propensity considerably. With the addition of $5 \mathrm{wt} \%$ and $10 \mathrm{wt} \%$ kaolinite, the ash deposition propensity is decreased by about $49 \%$ and $64 \%$, respectively. It is known that the main ash deposition mechanisms are inertial impaction, thermophoresis, and condensation. ${ }^{60}$ In the present work, the deposits formed by inertial impaction would dominate the deposit mass. Therefore, the observed decreased ash deposition propensity during kaolinite addition indicates that deposits formed by inertial impaction of fly ash particles will be reduced. This is most likely due to the smaller alkali chloride concentrations in the flue gas, caused by the injection of kaolinite particles. With depleted alkali chloride condensation, the stickiness of the fly ash particles and deposits would be reduced significantly, thus lowering the ash deposition propensity. A similar explanation may be applied for the decreased 


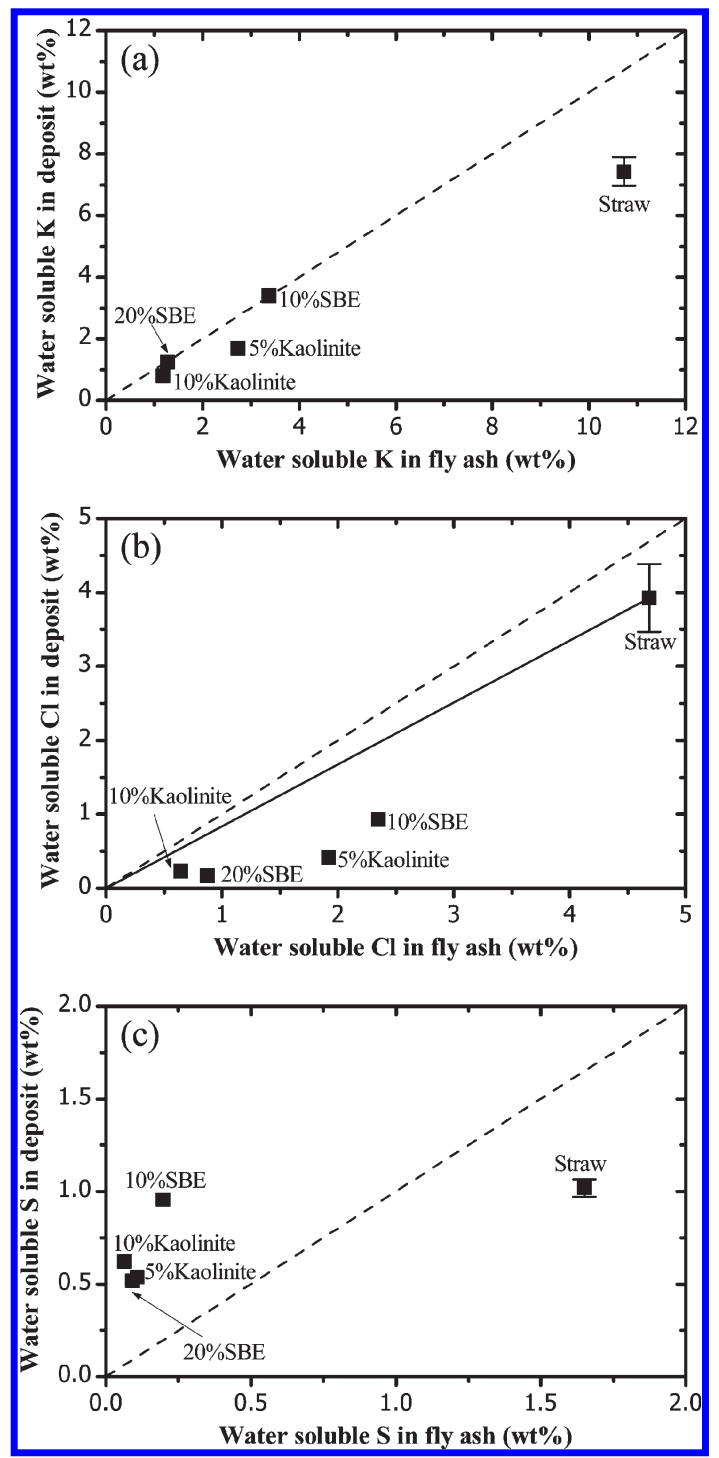

Figure 11. (a) Content of water-soluble $\mathrm{K}$ in deposit and fly ash, (b) content of water-soluble $\mathrm{Cl}$ in deposit and fly ash, and (c) content of water-soluble $\mathrm{S}$ in deposit and fly ash (the error bars indicate the deposit composition deviations of two repetition experiments on pure straw combustion).

ash deposition propensity during SBE addition. However, the observed ash deposition propensity during SBE addition is generally found to be larger than that of kaolinite addition. This is partly because of the kaolinite particles may react with gaseous alkali chlorides more effectively than the SBE particles, as discussed previously. In addition, the reaction between kaolinite and alkali chlorides may form alkali-aluminosilicates with high melting temperature, whereas the reaction between SBE and alkali chlorides may result in alkali silicates with a lower melting temperature.

The content of water-soluble $\mathrm{K}, \mathrm{S}$, and $\mathrm{Cl}$ in the collected deposits is analyzed and compared with that of the fly ash. It can be seen in Figure 11a that the water-soluble $\mathrm{K}$ content in the deposits is reduced considerably with the addition of kaolinite/ SBE, which is likely a result of both the dilution effect of kaolinite/SBE ash and the chemical effects discussed previously. During straw dust-firing, the water-soluble $\mathrm{K}$ content in the deposits is found to be lower than that of the fly ash. This may be explained by the deposition mechanisms of the water-soluble $\mathrm{K}$ species. During straw combustion, the majority of the watersoluble $\mathrm{K}$ species found in fly ash, such as $\mathrm{KCl}$ and $\mathrm{K}_{2} \mathrm{SO}_{4}$, will be present as vapor or small nucleates in flue gas. Therefore, the predominant deposition mechanisms for these species will be thermophoresis and condensation. However, the contribution of these mechanisms to the mass growth of deposit is minor and decrease quickly with time due to the decrease of temperature gradient between the flue gas and the deposit surface. ${ }^{61}$ Therefore, the deposition propensity of water-soluble $\mathrm{K}$ species is presumably lower than that of the larger Si rich fly ash particles where inertial impaction is the main deposition mechanism. This could be an explanation to the lower concentration of water-soluble $\mathrm{K}$ in the deposit as compared to the fly ash. With the addition of $\mathrm{SBE}$ and kaolinite, it seems that the content of water-soluble $\mathrm{K}$ in deposits becomes closer to that of fly ash. This may be due to that the addition of SBE and kaolinite increase the concentration of large fly ash particles, which may promote the condensation of the water-soluble $\mathrm{K}$ species on the large fly ash particles. In this way, the difference between the water-soluble $\mathrm{K}$ content in fly ash and deposition becomes smaller. The effect is particularly pronounced with SBE addition, as shown in Figure 11a.

Figure $11 \mathrm{~b}$ shows the water-soluble $\mathrm{Cl}$ content in the fly ash and deposit collected from different experiments. Since the water-soluble $\mathrm{Cl}$ content in the fly ash is found to be almost identical to the total $\mathrm{Cl}$ content, the results shown in Figure $11 \mathrm{~b}$ can be read as the total $\mathrm{Cl}$ content in fly ash and the deposit. It is seen that the $\mathrm{Cl}$ content in the deposit is decreased significantly with the addition of kaolinite or SBE, which is related both to the dilution effect of the ash from the additives as well as the chemical reactions between gaseous alkali chlorides and the additives. With the addition of 10 wt \% SBE and 20 wt \% SBE, the $\mathrm{Cl}$ content in deposit is decreased by approximately $75 \%$ and $95 \%$, respectively. This implies that the corrosion potential of the deposits will be significantly reduced. ${ }^{16,18}$ Compared to 10 wt $\%$ SBE addition, 5 wt \% kaolinite addition seems to reduce the $\mathrm{Cl}$ content in deposits more effectively. However, the reduction efficiency of 20 wt \% SBE addition seems to be slightly higher than that of $10 \mathrm{wt} \%$ kaolinite addition.

The $\mathrm{Cl}$ content in the deposits is generally found to be lower than that of the fly ash. This is partly linked to the deposition mechanism of alkali chlorides, which has been explained previously. However, another reason is that a condensed phase sulfation takes place after the deposition of the alkali chlorides. This reaction, which has been found to be significant at temperatures above $750{ }^{\circ} \mathrm{C}$, releases the deposited $\mathrm{Cl}$ as gaseous $\mathrm{HCl}^{62}$ Compared to pure straw combustion, the difference between the $\mathrm{Cl}$ contents of the deposits and the fly ash seems to become larger during the addition of kaolinite/SBE. This is presumably due to that the extent of the condensed phase sulfation reaction is higher when straw is mixed with additives. The measured $\mathrm{SO}_{2}$ concentration in pure straw combustion is 23 ppmv $\left(6 \% \mathrm{O}_{2}\right.$, dry). However, with the addition of 10 wt $\%$ and $20 \mathrm{wt} \% \mathrm{SBE}$, the $\mathrm{SO}_{2}$ concentration in the flue gas becomes 54 and 83 ppmv, respectively. The increased $\mathrm{SO}_{2}$ concentration during SBE addition is linked to the larger S content in SBE. In addition, the relatively large Si content in SBE may inhibit the gaseous sulphation reaction and thereby reduce the formation of sulfates, as illustrated in Figure 8a.

The influence of additives on the water-soluble $S$ content in the deposit is illustrated in Figure 11c. In general, the watersoluble $S$ content is decreased with the addition of additives, 
although the effect is not as significant as that of water-soluble $\mathrm{K}$ and Cl. This is partially due to the presence of the condensed phase sulfation reaction, which is clearly demonstrated by the higher water-soluble $S$ content in the deposit than that of fly ash. However, for pure straw combustion, the water-soluble $S$ content in fly ash seems to be larger than that in deposits. This may be explained by two reasons. First, as discussed previously, the main deposition mechanisms for water-soluble $S$ species are likely to be condensation and thermophoresis, which will conceivably result in a reduced deposition propensity of the $S$ species. Second, the extent of the sulfation reaction is probably quite limited during pure straw combustion, due to the low $\mathrm{SO}_{2}$ concentration in the flue gas.

The results shown in Figures 10 and 11 indicate that the addition of SBE can effectively decrease the $\mathrm{Cl}$ content in deposits, both through dilution and chemical reactions. Therefore, the corrosion potential in superheaters will be greatly decreased with the addition of SBE. Another advantage regarding corrosion is that the addition of $\mathrm{SBE}$ increases the $\mathrm{SO}_{2}$ concentration in flue gas, promoting gas phase sulfation. However, the ash deposition rate on superheaters may be slightly increased with SBE addition. Although the ash deposition propensity is reduced by SBE addition, the fly ash concentration in the flue gas is significantly increased. In addition, the melting temperature of the fly ash from SBE addition may be lower than that from kaolinite addition. Therefore, it is important to characterize melting behavior of the fly ash in order to assess the influence on deposit sintering and slagging formation. However, this is outside the scope of the present work.

\section{CONCLUSIONS}

Straw dust-firing experiments were carried out in an entrained flow reactor. For the straw used in the present work, the $\mathrm{Cl}$ was almost totally partitioned to the fly ash, with negligible $\mathrm{Cl}$ present in the bottom ash or in the flue gas. The morphology and composition of the fly ash from straw dust-firing indicated that the large fly ash particles $(>\sim 2.5 \mu \mathrm{m})$ were primarily molten or partial-molten spherical particles rich in $\mathrm{K}, \mathrm{Si}$, and $\mathrm{Ca}$, supplemented by some $\mathrm{Si}$ rich flake-shaped particles. The finer fly ash particles $(<\sim 2.5 \mu \mathrm{m})$ were predominantly formed from homogeneous nucleation followed by condensation and coagulation of the vaporized $\mathrm{K}, \mathrm{Cl}, \mathrm{S}$, and $\mathrm{P}$ species. Approximately $70 \%$ of the $\mathrm{K}$ in fly ash was found to be water-soluble, and $\mathrm{KCl}$ was estimated to contribute to more than $40 \%$ of the water-soluble $\mathrm{K}$. The results indicated a high deposition and corrosion potential of the fly ash from straw dust-firing.

The influence of two additives (spent bleaching earth (SBE) and kaolinite) on the ash chemistry and deposit formation during straw dust-firing was investigated and compared. It was shown that the SBE could react with the gaseous alkali released from straw combustion, resulting in reduced $\mathrm{Cl}$ retention in the fly ash, increased $\mathrm{SO}_{2}$ emission, and decreased formation of watersoluble alkalis. For the addition of 10 wt \% and 20 wt \% SBE, the alkali chloride formation in straw dust-firing was estimated to be reduced by about $39 \%$ and $67 \%$, respectively. With a similar molar ratio of $\mathrm{K} /(\mathrm{Al}+\mathrm{Si})$ in the fuel mixture, the inhibiting effect of kaolinite on alkali chloride formation was only slightly more pronounced than that of SBE. The $\mathrm{Cl}$ content in the deposits was decreased significantly with the addition of SBE, both due to a dilution effect and chemical reactions. With the addition of $10 \mathrm{wt} \%$ and $20 \mathrm{wt} \% \mathrm{SBE}$, the $\mathrm{Cl}$ content in the deposit was decreased by about $75 \%$ and $95 \%$, respectively, indicating that the corrosion potential of the superheaters could be greatly reduced with the addition of SBE. Compared to pure straw combustion, the ash deposition propensity was reduced by $\mathrm{SBE}$ addition. However, the ash deposition rate was increased, primarily due to the significantly higher fly ash concentration in the flue gas.

On the basis of the present work, it is suggested that SBE is a promising additive for straw dust-firing. Besides the identified effect on ash chemistry and deposition behavior, the SBE is characterized by high heating value, cheap price, negligible trace element concentration, and small particle size, which are favorable both from a technical and an economical point of view.

\section{ASSOCIATED CONTENT}

S Supporting Information. Method for calculating the ash and elemental balance shown in Figure 3. This material is available free of charge via the Internet at http://pubs.acs.org.

\section{AUTHOR INFORMATION}

\section{Corresponding Author}

*Phone: +45 4525 2927. Fax: +45 4588 2258. E-mail: haw@ kt.dtu.dk.

\section{ACKNOWLEDGMENT}

The work is part of the CHEC (Combustion and Harmful Emission Control) Research Center. The present work is sponsored by The Technical University of Denmark (DTU), ENERGINET.DK, BiofuelsGS-2 (Nordic Graduate School in Biofuel Science and Technolog-2), and The Danish Strategic Research Council (GREEN). We thank Aarhus Karlshamn AB for providing the spent bleaching earth. DONG Energy Power $\mathrm{A} / \mathrm{S}$ is acknowledged for the fuel/ash analysis at Enstedværket Laboratory. DTU CEN is thanked for the help in the SEM-EDS analysis.

\section{REFERENCES}

(1) Communication from the Commission to the European Parliament, the Council, the European Economic and Social Committee and the Committee of the Regions, 2020 by 2020 Europe's Climate Change Opportunity; Commission of the European Communities: Brussels, Belgium, 2008; Vol. COM, (2008) 30 final.

(2) Sander, B. In Bioenergy for Electricity and Heat - Experiences from Biomass-Fired CHP Plants in Denmark; DONG Energy: Fredericia, Denmark, 2007.

(3) Frandsen, F. J. Utilizing biomass and waste for power productiona decade of contributing to the understanding, interpretation and analysis of deposits and corrosion products. Fuel 2005, 84, 1277-1294.

(4) Zheng, Y.; Jensen, P. A.; Jensen, A. D.; Sander, B.; Junker, H. Ash transformation during co-firing coal and straw. Fuel 2007, 86, 1008-1020.

(5) Wu, H.; Pedersen, A. J.; Glarborg, P.; Frandsen, F. J.; DamJohansen, K.; Sander, B. Formation of fine particles in co-combustion of coal and solid recovered fuel in a pulverized coal-fired power station. Proc. Combust. Inst. 2011, 33, 2845-2852.

(6) Wu, H.; Glarborg, P.; Frandsen, F. J.; Dam-Johansen, K.; Jensen, P. A.; Sander, B. Co-combustion of pulverized coal and solid recovered fuel in an entrained flow reactor - General combustion and ash behaviour. Fuel 2011, 90, 1980-1991.

(7) A Visionary Danish Energy Policy 2025; Danish Energy Authority: Denmark, 2007. 
(8) Jenkins, B. M.; Baxter, L. L.; Miles, T. R., Jr; Miles, T. R. Combustion properties of biomass. Fuel Process. Technol. 1998, 54, 17-46.

(9) van Lith, S. C.; Alonso-Ramírez, V.; Jensen, P. A.; Frandsen, F. J.; Glarborg, P. Release to the gas phase of inorganic elements during wood combustion. Part 1: development and evaluation of quantification methods. Energy Fuels 2006, 20, 964-978.

(10) van Lith, S. C.; Jensen, P. A.; Frandsen, F. J.; Glarborg, P. Release to the Gas Phase of Inorganic Elements during Wood Combustion. Part 2: Influence of Fuel Composition. Energy Fuels 2008, 22, 1598-1609.

(11) Frandsen, F. J.; van Lith, S. C.; Korbee, R.; Yrjas, P.; Backman, R.; Obernberger, I.; Brunner, T.; Jöller, M. Quantification of the release of inorganic elements from biofuels. Fuel Process. Technol. 2007, 88, $1118-1128$.

(12) Knudsen, J. N.; Jensen, P. A.; Dam-Johansen, K. Transformation and release to the gas phase of $\mathrm{Cl}, \mathrm{K}$, and $\mathrm{S}$ during combustion of annual biomass. Energy Fuels 2004, 18, 1385-1399.

(13) Hupa, M. Interaction of fuels in co-firing in FBC. Fuel 2005, 84, 1312-1319.

(14) Davidsson, K. O.; Åmand, L. E.; Elled, A. L.; Leckner, B. Effect of cofiring coal and biofuel with sewage sludge on alkali problems in a circulating fluidized bed boiler. Energy Fuels 2007, 21, 3180-3188.

(15) Theis, M.; Skrifvars, B. J.; Zevenhoven, M.; Hupa, M.; Tran, H. Fouling tendency of ash resulting from burning mixtures of biofuels. Part 2: Deposit chemistry. Fuel 2006, 85, 1992-2001.

(16) Tillman, D. A.; Duong, D.; Miller, B. Chlorine in solid fuels fired in pulverized fuel boilers - sources, forms, reactions and consequences: a literature review. Energy Fuels 2009, 23, 3379-3391.

(17) Hansen, L. A.; Nielsen, H. P.; Frandsen, F. J.; Dam-Johansen, K.; Hørlyck, S.; Karlsson, A. Influence of deposit formation on corrosion at a straw-fired boiler. Fuel Process. Technol. 2000, 64, 189-209.

(18) Nielsen, H. P.; Frandsen, F. J.; Dam-Johansen, K.; Baxter, L. L. The implications of chlorine-associated corrosion on the operation of biomass-fired boilers. Prog. Enerov Combust. Sci. 2000, 26, 283-298.

(19) Michelsen, H. P.; Frandsen, F.; Dam-Johansen, K.; Larsen, O. H. Deposition and high temperature corrosion in a $10 \mathrm{MW}$ straw fired boiler. Fuel Process. Technol. 1998, 54, 95-108.

(20) Zeuthen, J. H.; Jensen, P. A.; Jensen, J. P.; Livbjerg, H. Aerosol formation during the combustion of straw with addition of sorbents. Energy Fuels 2007, 21, 699-709.

(21) Christensen, K. A.; Livbjerg, H. A field study of submicron particles from the combustion of straw. Aerosol Sci. Technol. 1996, 25, 185-199.

(22) Christensen, K. A.; Stenholm, M.; Livbjerg, H. The formation of submicron aerosol particles, $\mathrm{HCl}$ and $\mathrm{SO} 2$ in straw-fired boilers. I. Aerosol Sci. 1998, 29, 421-444.

(23) Zheng, Y.; Jensen, A. D.; Johnsson, J. E. Deactivation of V2O5WO3-TiO2 SCR catalyst at a biomass-fired combined heat and power plant. Appl. Catal., B: Environ 2005, 60, 253-264.

(24) Zheng, Y.; Jensen, A. D.; Johnsson, J. E. Laboratory investigation of selective catalytic reduction catalysts: Deactivation by potassium compounds and catalyst regeneration. Ind. Eng. Chem. Res. 2004, 43, 941-947.

(25) Castellino, F.; Rasmussen, S. B.; Jensen, A. D.; Johnsson, J. E.; Fehrmann, R. Deactivation of vanadia-based commercial SCR catalysts by polyphosphoric acids. Appl. Catal. B 2008, 83, 110-122.

(26) Castellino, F.; Jensen, A. D.; Johnsson, J. E.; Fehrmann, R. Influence of reaction products of $\mathrm{K}$-getter fuel additives on commercial vanadia-based SCR catalysts:: Part I. Potassium phosphate. Appl. Catal. B 2009, 86, 196-205.

(27) Aho, M.; Silvennoinen, J. Preventing chlorine deposition on heat transfer surfaces with aluminium-silicon rich biomass residue and additive. Fuel 2004, 83, 1299-1305.

(28) Steenari, B. M.; Lindqvist, O. High-temperature reactions of straw ash and the anti-sintering additives kaolin and dolomite. Biomass Bioenergy 1998, 14, 67-76.

(29) Aho, M.; Vainikka, P.; Taipale, R.; Yrjas, P. Effective new chemicals to prevent corrosion due to chlorine in power plant superheaters. Fuel 2008, 87, 647-654.
(30) Davidsson, K. O.; Åmand, L. E.; Steenari, B. M.; Elled, A. L.; Eskilsson, D.; Leckner, B. Countermeasures against alkali-related problems during combustion of biomass in a circulating fluidized bed boiler. Chem. Eng. Sci. 2008, 63, 5314-5329.

(31) Kassman, H.; Bäfver, L.; Åmand, L. E. The importance of SO2 and $\mathrm{SO} 3$ for sulphation of gaseous KCl-An experimental investigation in a biomass fired CFB boiler. Combust. Flame 2010, 157, 1649-1657.

(32) Tobiasen, L.; Skytte, R.; Pedersen, L. S.; Pedersen, S. T.; Lindberg, M. A. Deposit characteristic after injection of additives to a Danish straw-fired suspension boiler. Fuel Process. Technol. 2007, $88,1108-1117$.

(33) Boström, D.; Grimm, A.; Boman, C.; Björnbom, E.; Öhman, M. Influence of Kaolin and Calcite Additives on Ash Transformations in Small-Scale Combustion of Oat. Energy Fuels 2009, 23, 5184-5190.

(34) Bäfver, L. S.; Rönnbäck, M.; Leckner, B.; Claesson, F.; Tullin, C. Particle emission from combustion of oat grain and its potential reduction by addition of limestone or kaolin. Fuel Process. Technol. 2009, 90, 353-359.

(35) Mwabe, P. O.; Wendt, J. O. L. Mechanisms governing trace sodium capture by kaolinite in a downflow combustor. Proc. Combust. Inst. 1996, 26, 2447-2453.

(36) Gale, T. K.; Wendt, J. O. L. High-temperature interactions between multiple-metals and kaolinite. Combust. Flame 2002, 131, 299-307.

(37) Zheng, Y.; Jensen, P. A.; Jensen, A. D. A kinetic study of gaseous potassium capture by coal minerals in a high temperature fixed-bed reactor. Fuel 2008, 87, 3304-3312.

(38) Uberoi, M.; Punjak, W. A.; Shadman, F. The kinetics and mechanism of alkali removal from flue gases by solid sorbents. Prog. Energy Combust. Sci. 1990, 16, 205-211.

(39) Iisa, K.; Lu, Y.; Salmenoja, K. Sulfation of potassium chloride at combustion conditions. Energv Fuels 1999, 13, 1184-1190.

(40) Novaković, A.; van Lith, S. C.; Frandsen, F. J.; Jensen, P. A.; Holgersen, L. B. Release of Potassium from the Systems K- Ca- Si and K- Ca- P. Energy Fuels 2009, 23, 3423-3428.

(41) Glarborg, P.; Marshall, P. Mechanism and modeling of the formation of gaseous alkali sulfates. Combust. Flame 2005, 141, 22-39.

(42) Almark, M.; Edvardsson, E.; Berg, M. Reduction of alkali chlorides in flue gas and chlorine in deposits by phosphate addition. In Proceedings of the Impacts of Fuel Quality on Power Generation and the Environment; Lapland, Finland, 2010.

(43) Pedersen, L. S.; Nielsen, H. P.; Kiil, S.; Hansen, L. A.; DamJohansen, K.; Kildsig, F.; Christensen, J.; Jespersen, P. Full-scale co-firing of straw and coal. Fuel 1996, 75, 1584-1590.

(44) Tsai, W. T.; Chen, H. P.; Hsieh, M. F.; Sun, H. F.; Chien, S. F. Regeneration of spent bleaching earth by pyrolysis in a rotary furnace. L. Anal. Appl. Pyrolysis 2002, 63, 157-170.

(45) Tobiasen, L.; Knudsen, J. Alternative Additives (PSO FU 6532); DONG Energy: Fredericia, Denmark, 2007.

(46) Yin, C.; Rosendahl, L. A.; Kær, S. K. Grate-firing of biomass for heat and power production. Prog. Energy Combust. Sci. 2008, 34, $725-754$.

(47) Baxter, L. L.; Miles, T. R.; Miles, T. R., Jr; Jenkins, B. M.; Milne, T.; Dayton, D.; Bryers, R. W.; Oden, L. L. The behavior of inorganic material in biomass-fired power boilers: field and laboratory experiences. Fuel Process. Technol. 1998, 54, 47-78.

(48) Christensen, K. A.; Livbjerg, H. A plug flow model for chemical reactions and aerosol nucleation and growth in an alkali-containing flue gas. Aerosol Sci. Technol. 2000, 33, 470-489.

(49) Jensen, J. R.; Nielsen, L. B.; Schultz-Møller, C.; Wedel, S.; Livbjerg, $\mathrm{H}$. The nucleation of aerosols in flue gases with a high content of alkali-A laboratory study. Aerosol Sci. Technol. 2000, 33, 490-509.

(50) Linak, W. P.; Miller, C. A.; Seames, W. S.; Wendt, J. O. L.; Ishinomori, T.; Endo, Y.; Miyamae, S. On trimodal particle size distributions in fly ash from pulverized-coal combustion. Proc. Combust. Inst. 2002, 29, 441-447.

(51) Wolf, K. J.; Smeda, A.; Müller, M.; Hilpert, K. Investigations on the influence of additives for $\mathrm{SO} 2$ reduction during high alkaline biomass combustion. Enerov Fuels 2005, 19, 820-824. 
(52) Tran, K. Q.; Iisa, K.; Steenari, B. M.; Lindqvist, O. A kinetic study of gaseous alkali capture by kaolin in the fixed bed reactor equipped with an alkali detector. Fuel 2005, 84, 169-175.

(53) Wei, X.; Schnell, U.; Hein, K. R. G. Behaviour of gaseous chlorine and alkali metals during biomass thermal utilisation. Fuel 2005, 84, 841-848.

(54) Nielsen, H. P.; Baxter, L. L.; Sclippab, G.; Morey, C.; Frandsen, F. J.; Dam-Johansen, K. Deposition of potassium salts on heat transfer surfaces in straw-fired boilers: a pilot-scale study. Fuel 2000, 79, 131-139.

(55) Lin, W.; Dam-Johansen, K.; Frandsen, F. Agglomeration in biofuel fired fluidized bed combustors. Chem. Eng. I. 2003, 96, 171-185.

(56) Wei, X.; Lopez, C.; von Puttkamer, T.; Schnell, U.; Unterberger, S.; Hein, K. R. G. Assessment of Chlorine- Alkali- Mineral Interactions during Co-Combustion of Coal and Straw. Energy Fuels 2002, 16, 10951108.

(57) Vuthaluru, H. B.; Vleeskens, J. M.; Wall, T. F. Reducing fouling from brown coals by sodium-binding additives. Fuel Process. Technol. 1998, 55, 161-173.

(58) Lindner, E. R.; Wall, T. F. Sodium ash reactions during combustion of pulverised coal. Proc. Combust. Inst. 1991, 23, 1313-1321.

(59) Linak, W. P.; Wendt, J. O. L. Toxic metal emissions from incineration: mechanisms and control. Prog. Energy Combust. Sci. 1993, 19, 145-185.

(60) Baxter, L. L. Ash deposition during biomass and coal combustion: a mechanistic approach. Biomass Bioenergy 1993, 4, 85-102.

(61) Zhou, H.; Jensen, P. A.; Frandsen, F. J. Dynamic mechanistic model of superheater deposit growth and shedding in a biomass fired grate boiler. Fuel 2007, 86, 1519-1533.

(62) Matsuda, H.; Ozawa, S.; Naruse, K.; Ito, K.; Kojima, Y.; Yanase, T. Kinetics of $\mathrm{HCl}$ emission from inorganic chlorides in simulated municipal wastes incineration conditions. Chem. Eng. Sci. 2005, 60, 545-552. 